\title{
Evaluation of moving-bed biofilm sequencing batch reactor (MBSBR) in operating A2O process with emphasis on biological removal of nutrients existing in wastewater
}

Seyedsalehi, M.; Jaafari, J.; Hélix-Nielsen, Claus; Hodaifa, G.; Manshouri, M.; Ghadimi, S.; Hafizi, H.; Barzanouni, $\mathbf{H}$.

Published in:

International Journal of Environmental Science and Technology

Link to article, DOI:

$10.1007 / \mathrm{s} 13762-017-1360-9$

Publication date:

2018

Document Version

Peer reviewed version

Link back to DTU Orbit

Citation (APA):

Seyedsalehi, M., Jaafari, J., Hélix-Nielsen, C., Hodaifa, G., Manshouri, M., Ghadimi, S., Hafizi, НH., \& Barzanouni, $H$. (2018). Evaluation of moving-bed biofilm sequencing batch reactor (MBSBR) in operating $A{ }^{2} O$ process with emphasis on biological removal of nutrients existing in wastewater. International Journal of Environmental Science and Technology, 15(1), 199-206. https://doi.org/10.1007/s13762-017-1360-9

\section{General rights}

Copyright and moral rights for the publications made accessible in the public portal are retained by the authors and/or other copyright owners and it is a condition of accessing publications that users recognise and abide by the legal requirements associated with these rights.

- Users may download and print one copy of any publication from the public portal for the purpose of private study or research.

- You may not further distribute the material or use it for any profit-making activity or commercial gain

- You may freely distribute the URL identifying the publication in the public portal 


\title{
Full title: Evaluation of Moving-Bed Biofilm Sequencing Batch Reactor (MBSBR) in Operating $\mathrm{A}^{2} \mathrm{O}$ Process with Emphasis on Biological Removal of Nutrients Existing in Wastewater
}

\section{Running title: Evaluation of MBSBR in Operating A2O Process}

\begin{abstract}
In this study, the performance of Moving-Bed Biofilm Sequencing Batch Reactor (MBSBR) in operating the Anaerobic/Anoxic/Oxic $\left(\mathrm{A}^{2} \mathrm{O}\right)$ process for treatment of wastewaters containing nitrogen and phosphorous was evaluated. For this purpose, two bench scale SBR reactors with a total volume of $30 \mathrm{~L}$ and functional volume of $10 \mathrm{~L}$ were used. The pilot was made of Plexiglass, in which 60 percent of the functional volume consisted of PVC (Kaldnes K3 type) with a specific surface area of $560 \mathrm{~m}^{2} / \mathrm{m}^{3}$. The independent variables used in this study were Hydraulic Retention Time (HRT) (1.5, 2, 2.5, 3, and 3.5 h) and organic load (300, 500, 800, $1000 \mathrm{mg} / \mathrm{L}$ ). The results showed impressive performance in an organic load of $300 \mathrm{mg} / \mathrm{L}$ and HRT of $3 \mathrm{~h}$ with maximum removal of COD and TN respectively by 95.12 and 89.8 percent and in an organic load of $1000 \mathrm{mg} / \mathrm{L}$ and HRT of $3.5 \mathrm{~h}$ with maximum TP removal of 72.33 percent. Therefore, according to the analysis of data obtained by different HRTs, it was revealed that the system of $\mathrm{A}^{2} \mathrm{O}$ has the greater efficiency in the shortest possible time for removing organic matters from wastewater.
\end{abstract}

Keywords: $\mathrm{A}_{2} \mathrm{O}$, Biofilm Reactor, MBSBR, Municipal Wastewater, Nutrients

\section{Introduction}

Nitrate and phosphate are potential pollutants of water resources and are entered through different wastewaters as well as contamination by manure and chemical fertilizers (Naghipour et al., 2015, Ashrafi et al., 2016, Agarwal et al., 2016). Phosphorous compounds are commonly used in various consumer products and industries such as: fertilizers, water softening, detergents, metallurgy, paints, food, beverages, and pharmaceuticals. Phosphate pollution can increase cellular mass and create numerous problems alongside increase in the concentration of nitrate in water (Safari et al., 2015, Naghipour et al., 2016). High levels of nitrate concentration in water are a known cause of methaemoglobin in newborns under six months (Sadler et al., 2016). It also affects animals and increases the rate of abortion (Esfandyari et al., 
2015, Hassani et al., 2014). In individuals that lack the converting enzyme of methaemoglobin to haemoglobin, increases in the concentration of nitrate can be dangerous. Gastric cancer is another adverse effect of nitrate in water (Safari et al., 2015). Thus, the most important factor in eliminating disease associated with increased nitrate levels in water in both humans and animals is preventing the entry of nitrate (Jafari et al., 2013, Jaafari et al., 2014). Also, the depletion of $\mathrm{NH}^{4+}$ in watery places causes toxicity for watery animals especially fish and in high density 0.2 to $0.5 \mathrm{mg} / 1$ it will be fatal (Bessbousse et al., 2008).

Different methods of nutrient removal such as chemical precipitation (Clark et al., 1997), membrane technologies (Geng et al., 2007), ion exchange (Blaney et al., 2007) and adsorption (Tian et al., 2009) have been used previously. Each of these methods has specific advantages and disadvantages. Among these available alternatives, biological processes have gained greater attention due to advantages such as less sludge production, more flexibility, and lower cost compared to chemical methods. To address the importance of these environmental pollutants, these designed mechanisms have altered the activated sludge process in order to completely remove pollutants, relying on the elimination of phosphorus and nitrate performed separately or together (Jaafari et al., 2014, Balarak et al., 2015, Seyedsalehi et al., J. Jaafari, 2016). Removing nitrate and phosphorus together through various systems prevents the adverse effects resulting from the oxidation of nitrogen compounds during phosphorus removal process with the ease of combining activated sludge process and achieving recommended standards (Shahmoradi et al., 2006, Irani et al., 2016).

The main idea of biofilm innovation was developing systems that have the advantages of activated sludge processes and biofilm systems including 1) capability for treatment of all domestic and industrial wastewaters 2) shockability 3) being compact 4) no need to return sludge and its disadvantages such as pressure drop, platform eclipse, reverse washout and etc. The Moving Bed Biofilm Reactor (MBBR) is a highly effective biological treatment process that was developed on the basis of conventional activated sludge process and bio-filter process. The activated sludge and biomass are intermixed and grown on small carrier elements that have slightly lighter density than water and are circulated by a water stream inside the reactor. Based on studies in Iran and around the world, Bina et al (2005) investigated the effect of input $\mathrm{COD} / \mathrm{N}$ on the rate of nitrification in wastewater treatment using a pilot scale reactor. The results showed that high concentrations of organic carbon are a deterrent for nitrification and there is an inverse relationship between the concentration of carbon and nitrification rate (Bina et al., 2005). The Sequential batch reactor method SBR was first introduced by Arden and Lockett in 1914 which was based on active biomass process (Arden and 
Lockett, 1914). A SBR system may be used as a single tank or multiple parallel tanks. Managing the cost, decreasing the operational difficulties, and increasing the efficiency of wastewater treatment systems without the increase in time and cost are issues that have led environmental engineers to create new processes in wastewater engineering (Chen et al., 2014). In recent years, some new processes have been developed to achieve biological nutrient removal and factors that can be effect in efficiency such as configuration of sequencing batch reactor (Wang et al., 2014, Chen et al., 2016), different carbon sources (Chen et al., 2015), tempreture (Chen et al., 2014).

According to the suitable features mentioned for this system, a moving-bed biofilm sequencing batch reactor (MBSBR) operated in three stages: anaerobic, anoxic, and aerobic $\left(\mathrm{A}^{2} \mathrm{O}\right) \cdot \mathrm{A}^{2} \mathrm{O}$ process was used with emphasis on the removal of biological nutrients existing in wastewater in different organic loading rate and determining the operating principles.

\section{Materials and methods}

\section{Moving-bed biofilm sequencing batch reactors}

This experiment involved applied research, where an experimental pilot was configured. For this purpose, after necessary studies such as purchasing laboratory equipment, Instrumentation, making the pilot and performing the final checking, the pilot was installed in the Sahebgharanieh wastewater treatment plant, using information found in scientific references. The pilot includes two Plexiglass reservoirs that are fixed on a metal framework equipped with a mixer that is controlled by a digital control system. An anaerobic reactor and an anoxicaerobic reactor that combined the treatment circuit with the schematic design of $\mathrm{A}^{2} \mathrm{O}$ are shown in figure 1 . The characteristics of bioreactors are given in table 1. 


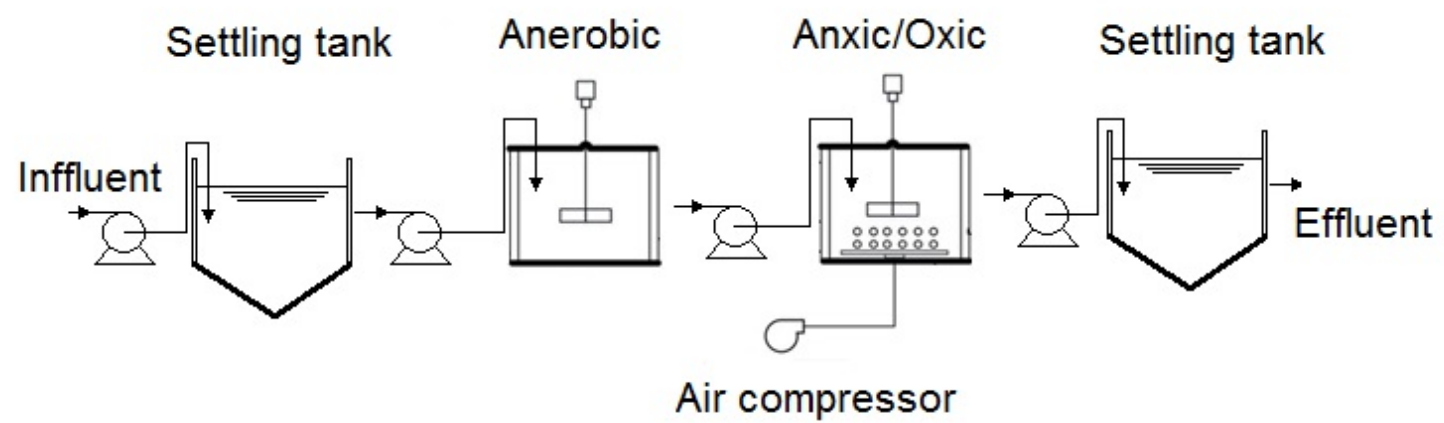

Fig 1. Schematic of $\mathrm{A}^{2} \mathrm{O}$ with emphasis on nutrient biological removal

Table 1. Characteristics of bioreactors used in this study

\begin{tabular}{c|c|c|c}
\hline Parameters & Anaerobic & Aerobic/Anoxic & Unit \\
\hline Reactor type & Plexiglass & Plexiglass & - \\
\hline Wall thickness & 5 & 5 & $\mathrm{~mm}$ \\
\hline Internal length & 25.5 & 25.5 & $\mathrm{Cm}$ \\
\hline Internal width & 25.5 & 25 & $\mathrm{Cm}$ \\
\hline Reactor height & 30 & 54 & $\mathrm{Cm}$ \\
\hline Free space & 10 & 10 & $\mathrm{Cm}$ \\
\hline Total volume of the pilot & 20 & 30 & $(\mathrm{~L})$ \\
\hline Useful volume of the pilot & 10 & 20 & $(\mathrm{~L})$ \\
\hline Filling percent with media & 60 & 60 & $\%$ \\
\hline
\end{tabular}

The aeration system of the aerobic/anoxic pilot was equipped with a diffuser installed in the bottom of the pilot and the required air was supplied by a Side Channel brand air compressor with a nominal capacity of $180 \mathrm{~L} / \mathrm{min}$. The supplied pumps were a Matrix brand with 40L/Min discharge and discharge height of 38 meters. The temperature of bioreactors was kept constant in the range of $21-25^{\circ} \mathrm{C}$ by means of smart aquarium heaters. The media used in $\mathrm{A}^{2} \mathrm{O}$ process was K3. Kaldnes media is one of the most commonly used and in making the results of this study applicable and economical, K3 was used in spite of lack of production in Iran. 60 percent of the system volume was filled with these media (Bina et al., 2005). Characteristics of these media can be found in table 2 . 
Table 2. Characteristics of media used in this study (Bina et al., 2005)

\begin{tabular}{|c|c|c|c|}
\hline Parameters & Anaerobic & Aerobic/Anoxic & Unit \\
\hline Reactor type & Plexiglass & Plexiglass & - \\
\hline Wall thickness & 5 & 5 & $\mathrm{~mm}$ \\
\hline Internal length & 25.5 & 25.5 & $\mathrm{Cm}$ \\
\hline Internal width & 25.5 & 25 & $\mathrm{Cm}$ \\
\hline Reactor height & 30 & 54 & $\mathrm{Cm}$ \\
\hline Free space & 10 & 10 & $\mathrm{Cm}$ \\
\hline Total volume of the pilot & 20 & 30 & (L) \\
\hline Useful volume of the pilot & 10 & 20 & $\%$ \\
\hline Filling percent with media & 60 & 60 & \\
\hline
\end{tabular}

To launch the pilots, all connections were controlled in terms of any leakage and it was ensured that parts in contact with electricity were insulated against water. The feeding reservoir was a 220 litres tank that had been previously graded and connected to the feeding pump using a transparent soft hose. To ensure the accuracy of the equipment, the system was tested by filling the feeding tank with water in 2 hours cycles for a week.

\section{Startup}

After testing the system and confirming the accuracy of pilot operation, activated sludge from the returned line was transferred from Mahalati wastewater treatment plant so that one third of the volume of the pilot was filled. At this step, in order to form the biofilm on the beds, manual feeding to the pilot was performed for a week out of the working cycle. Then, the synthetic wastewater was transferred into the pilots in 2-hour cycles. The input feeding quantity to the pilot was 10 litres per cycle that was 3 times diluted. Prepared synthetic wastewater contained milk powder, glucose, urea, $\mathrm{KH}_{2} \mathrm{PO}_{4}$ and $\mathrm{K}_{2} \mathrm{HPO}_{4}$. Planned time cycles for the pilot included feeding the wastewater, an aeration time with mixer movement, anoxic time in the first pilot, aeration time in the first pilot, anoxic time in the second pilot, aeration time in the second pilot, sedimentation time, discharge and relaxing time.

To adapt the sludge with synthetic sewage, wastewater containing different concentrations of COD was injected into the system, in a two-hour cycle by sewage containing an organic load of $300 \mathrm{mg} / \mathrm{L}$ for three weeks. It should be noted that in the first week, only static anaerobic phase for 1 hour and then aeration phase for two hours were employed. This first week was considered only for biofilm formation on the media. In the next two weeks, the system (predefined) was operated in anaerobic phase with thorough mixing for 30 minutes, in anoxic 
phase with thorough mixing for 30 minutes in both pilots, and in aeration phase with thorough aeration for 1 hour in both pilots. Adaptation was completely conducted in these three weeks to the synthetic wastewater containing carbonaceous materials such as glucose, milk powder and micronutrients that were supplied by milk powder. After these three weeks, with the same conditions, synthetic wastewater type was changed by entering nutrients. The system underwent adaptation in the same conditions for a week, and tests were conducted since the fifth week. After completing the tests in the first operation conditions with four changes in HRT (1.5-3 h), another adaptation began by changing the feed type. Then, to achieve $500 \mathrm{mg} / \mathrm{L}$ COD, feeding the ingredients especially micronutrients were using stoichiometric relationships and in respect to COD:N:P ratio as 100:5:1 in reservoir useful volume of 200 litres. Next, the system was adapted in defined phase conditions and experiments related to this step with four changes in HRT were conducted. After completing tests in this step, the system entered the third change in feeding. In this step, the system was adapted with quality conditions (COD $=800$ $\mathrm{MG} / \mathrm{L})$ for a week, before tests began with emphasis on five different HRTs $(+3.5 \mathrm{~h})$. The last changes in feeding began after these experiments. The purpose of this step was making a synthetic wastewater with COD of $1000 \mathrm{mg} / \mathrm{L}$. Similar to previous steps, the time for adaptation was a week and then, tests were performed with five changes in HRT. Therfure the SBR was operated under 300, 500, 800 and $1000 \mathrm{mg} / \mathrm{L}$ respectively.

\section{Analytical methods}

All tests were conducted based on the instructions presented in APHA standard methods for the examination of water and wastewater (APHA, 1992). Meaning that measuring the phosphorus and nitrogen quantities were respectively based on standards 4500-p and 4500Norg. COD was measured using indicators of HACH Company, and the DDR5000 device was performed according to the standard method for examination of water and wastewater. All chemicals used in this study were produced by Merck Company.

\section{Results and discussion}

Data was analysed after collecting them through the experiments. According to the analysis of figure 2, it was observed that the $\mathrm{A}^{2} \mathrm{O}$ system by MBSBR has a high efficiency in removal of organic matters from wastewater. The SBR was operated under four intial COD concentrations of $300,500,800$ and $1000 \mathrm{mg} / \mathrm{L}$. It was found that the maximum removal efficiency between four hydraulic retention times was gained in HRT of 3 hours respectively with 95.12 and 91.91 
percent for 300 and $500 \mathrm{mg} / \mathrm{L}$ of entering COD. In the above COD concentration at 800 and $1000 \mathrm{mg} / \mathrm{L}$, a new hydraulic retention time was added to the end of the research exclusively for studying removal efficiency of phosphorus. In 800 and $1000 \mathrm{mg} / \mathrm{L}$ of COD, maximum removal efficiency between five hydraulic retention times was gained in HRT of 3.5 hours respectively with 92.08 and 86.18 percent. As observed and expected, the removal efficiency of COD increased with an increase in the hydraulic retention time and more adaptation.

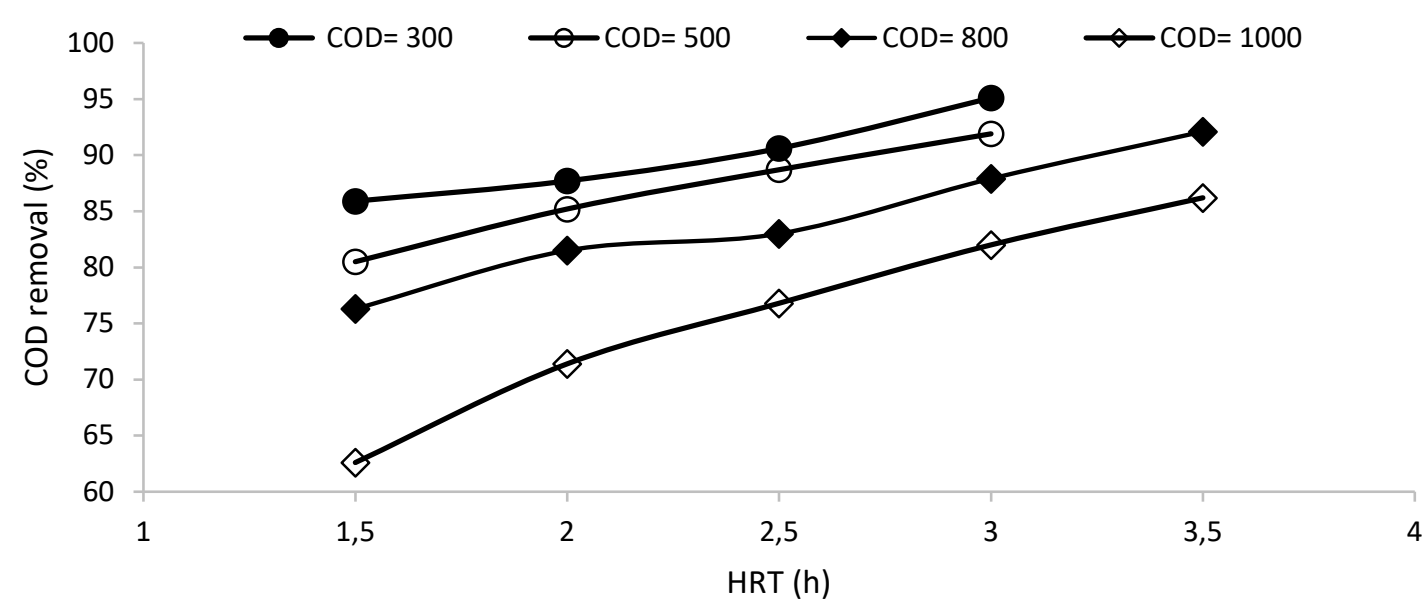

Fig 2. COD removal efficiency in different HRTs of $\mathrm{A}^{2} \mathrm{O}$ process.

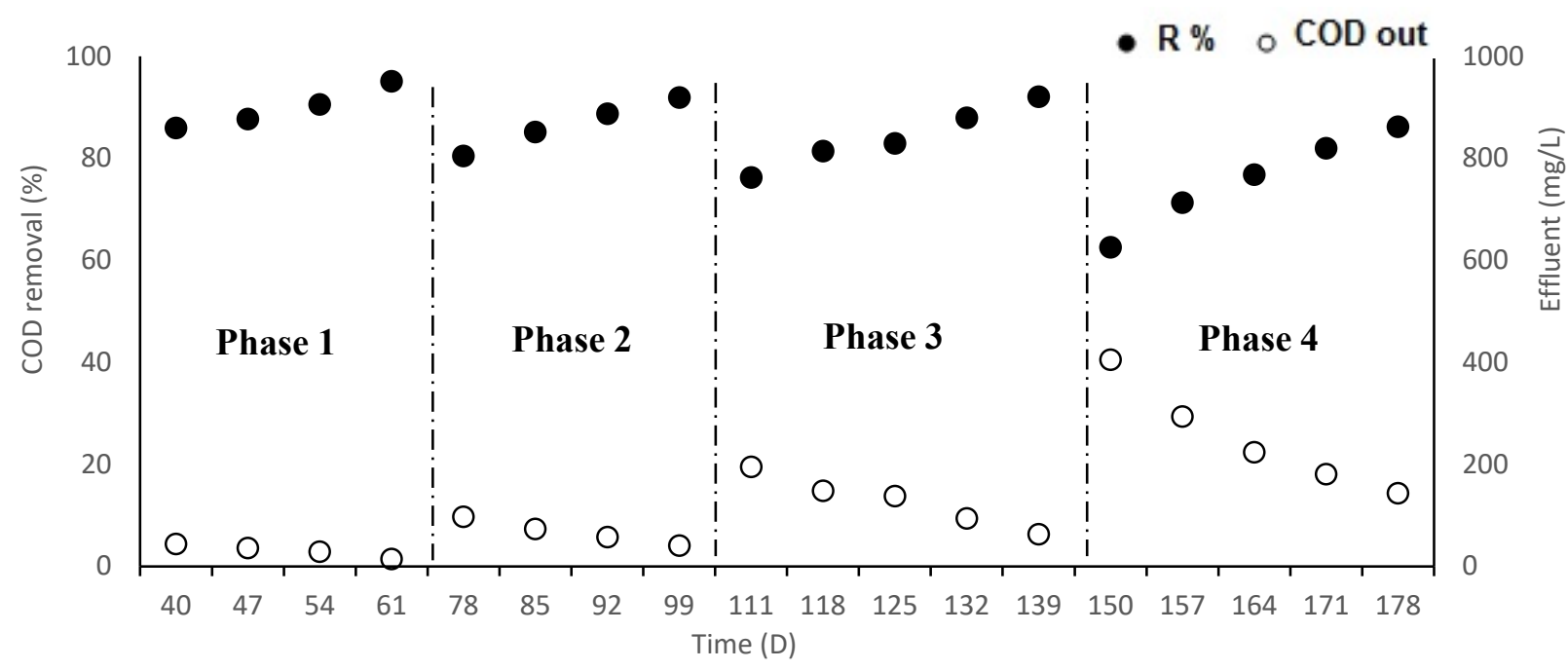

Fig 3. COD removal efficiency and output $\mathrm{COD}$ against the time in $\mathrm{A}^{2} \mathrm{O}$ process.

As observed in figure 3, shockability of the system in high levels is prevalent so that the system reacts rapidly and adapts itself to the new condition flexibly. 
According to figure 4, the $\mathrm{A}^{2} \mathrm{O}$ system by MBSBR had a high capability in removal of nitrogen compounds from wastewater. Clearly, in CODs of 300 and $500 \mathrm{mg} / \mathrm{L}$, maximum removal efficiency of TN between four hydraulic retention times in 61 and 99 working days was gained in HRT of 3 hours, respectively 98.8 and 88 percent. In two input organic loads of 800 and $1000 \mathrm{mg} / \mathrm{L}$, maximum removal efficiency of TN between five hydraulic retention times in 139 and 178 working days was gained in HRT of 3.5 hours, respectively 79.4 and 73.1 percent. As observed and expected, removal efficiency of TN increased with an increase in the hydraulic retention time in each phase and more adaptation.

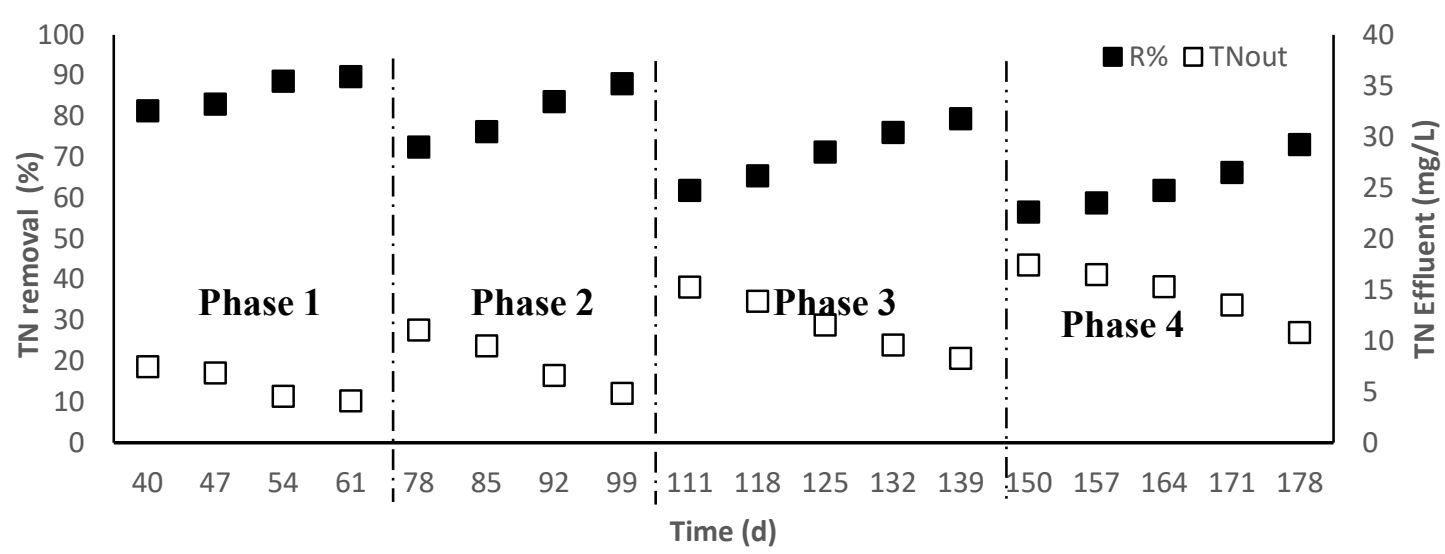

Fig 4. Removal efficiency of $\mathrm{TN}$ and output $\mathrm{TN}$ against the time in $\mathrm{A}^{2} \mathrm{O}$ process

According to figure 5, it was observed that $\mathrm{A}^{2} \mathrm{O}$ by MBSBR had a high capability in removal of TP from municipal wastewater. Clearly, in an input organic load of 300 and $500 \mathrm{mg} / \mathrm{L}$, maximum removal efficiency of TP between four hydraulic retention times in 61 and 99 working days was gained in HRT of 3 hours, respectively 48.2 and 58.7 percent. In two input organic loads of 800 and $1000 \mathrm{mg} / \mathrm{L}$, maximum removal efficiency of TP between five hydraulic retention times in 139 and 178 working days was gained in HRT of 3.5 hours, respectively 64.7 and 72.3 percent. As observed and expected, removal efficiency of TP increased with the increase in the hydraulic retention time in each phase and more adaptation. 


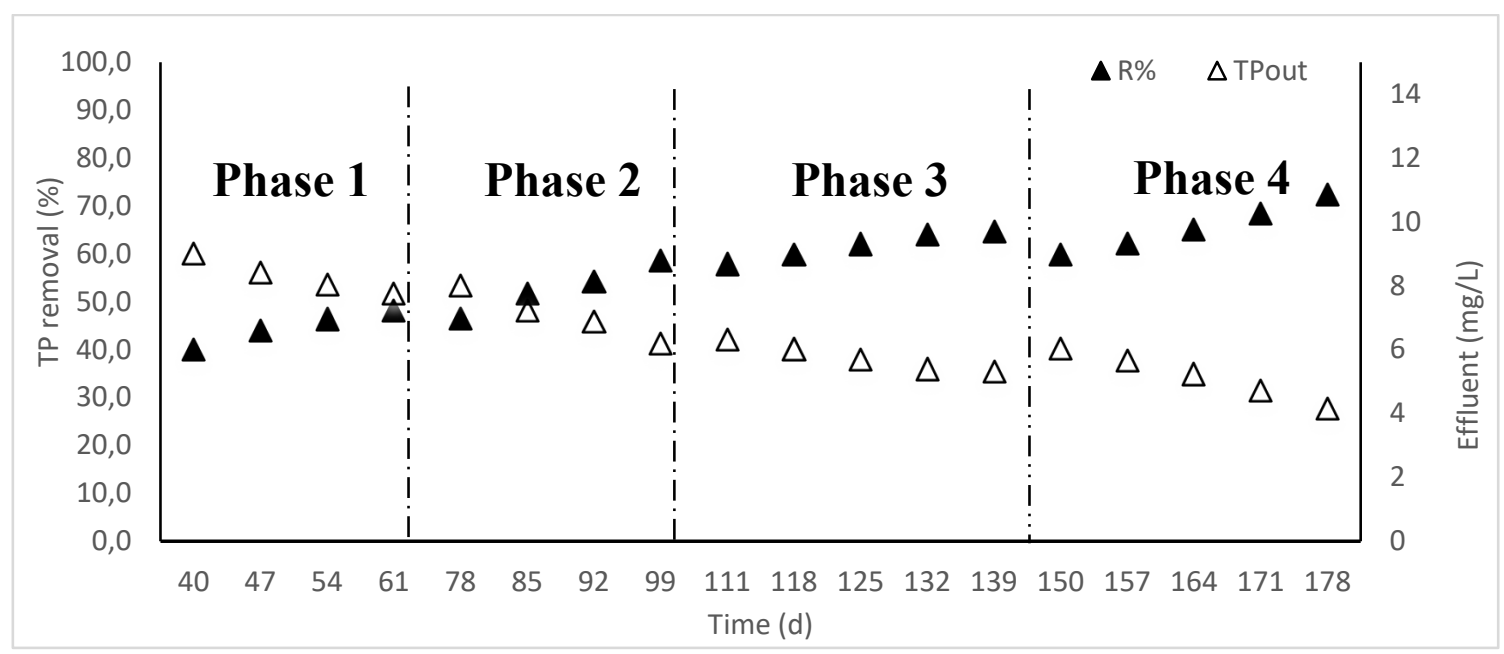

Fig 5. Removal efficiency of $\mathrm{TP}$ and output $\mathrm{TP}$ against the time in $\mathrm{A}^{2} \mathrm{O}$ process

Analysis of nitrogen organic matter removal method in anaerobic and aerobic/anoxic areas follows due to the low $\mathrm{PH}$ in the output wastewater from anaerobic unit and nitrifiers' requirement of low acidity and high basicity. There is a probability of reduction in denitrification process and increase in biological degradable organic matters (like organic acids existing in anaerobic area), leading to an increase in the BOD/TKN ratio in an aerobic area and decrease in nitrification. Nitrifying Bacteria need the mineral carbon for the interaction. If the quantity of organic carbon increases in the system, it will pose an important obstacle in the oxidation of the nitrogen compounds. Heterotrophs and nitrifiers will compete for achieving oxygen and rapid growth of heterotrophs, leading to a decrease in nitrifier population in the biofilm (Rusten et al., 1995). In attached growth systems, when the concentration of oxygen is close to zero in the depth of biofilm, denitrification will occur. Therefore, both nitrification and denitrification processes occur simultaneously, which leads to further nitrogen removal from wastewater in these systems (Ahmed et al., 2007). Results showed that total output nitrogen was less than total input nitrogen in all four system operation phases, and the system had a satisfying efficiency in removal of nitrogen compounds at a retention time of 3 hours and organic load of $300 \mathrm{mg} / \mathrm{L}$. The removal efficiency was 89.8 percent, which was higher than the discharge standard to the surface waters. One of the most important reasons is to correct simultaneous operation of two anoxic and aeration phases without recycling of the nitrate over the system. The important role of SRT in operation of the system should also be noted. Ahmad and et al revealed that in the aerobic-anaerobic wastewater treatment, maximum removal efficiency of ammoniac nitrogen is 84.62 percent and its output concentration is $1.11 \mathrm{mg} / \mathrm{L}$, 
and for every ten percent of nitrogen removal, three percent of changes in $\mathrm{PH}$ is achieved (Ahmed et al., 2007, Jayaraj and Latha, 2010). This showed that the aerobic-anaerobic fixed bed reactor with high flow (UA/AFB) and hydraulic retention time of 7 hours had simultaneous removal of COD, nitrification, and denitrification respectively at 90, 93 and 88 percent. Maximum removal of ammoniac nitrogen was in the aerobic area and for nitrate nitrogen was in the anaerobic area while denitrification is increased with a decrease in the retention time. This is due to shot retention time, where the highest quantity of organic materials such as acetate is present and desirable for denitrifiers. Generally, biological removal of phosphorus follows under anaerobic conditions when volatile fatty acids (VFAs) are converted to degradable organic matters (bsCOD) through fermentation and then, are stored in the cellular inner granulates such as Polyhydroxybutyrate (PHBs) by PAOs. The energy required to store PHBs in the anaerobic condition is supplied by breaking stored poly phosphate that leads to degradation of ortho phosphates and increase in their concentration in the liquid. Under aerobic conditions, PAOs consume the stored PHBs and through this process, they achieve the energy needed to grow and absorb the ortho phosphate from the liquid (Tchobanoglous et al., 2003). The comparison of the average removal efficiencies in four different retention times reveals a meaningful difference between the effectiveness of increasing time in aerobic and anaerobic parts of $\mathrm{A}^{2} \mathrm{O}$ system by MBSBR in removal of phosphorus. According to the study conducted about effectiveness of SBR reactor in biological removal of phosphorus, Dehghani and Kermanshahi (2009) showed that the most suitable operating cycle for phosphorus removal is 35.2 percent which can be enhanced to 60.91 percent by increasing the sludge life to 5 days with an anaerobic time of 2 hours, aerobic time of 18 hours, and anoxic time of 4 hours.

\section{Conclusion}

Analysis of COD removal efficiency in different hydraulic retention times showed that the $\mathrm{A}^{2} \mathrm{O}$ system has the highest efficiency in the shortest possible time for removing organic matters from wastewater. The analysis of total nitrogen removal efficiency in different hydraulic retention times revealed that the $\mathrm{A}^{2} \mathrm{O}$ system has a high capability for removing organic nitrogen from wastewater in the shortest time. As observed, increases in organic load had an important impact on decreasing the total nitrogen removal efficiency, which could be due to the quality shock in the starting moments. As observed and expected in the study, nitrogen removal was increased over the operating time and more adaptation of the system. The reason behind high removal efficiency of total nitrogen could be the similarity of both anoxic and 
aerobic reactors in a research pilot. This would lead to disconnection of the nitrate internal recycle line and result in an increase in the total nitrogen removal efficiency. Consequently, to promote the total nitrogen removal efficiency in advanced treatment plants, it is recommended to use the nitrate recycling method with 100 to 150 percent proportion in operation considerations. According to the data obtained from phosphorus removal efficiency in the $\mathrm{A}^{2} \mathrm{O}$ system by biofilm bioreactors, it is revealed that phosphorus removal efficiency is simultaneously increased with increases in the organic load. After increasing of organic load, in intial phase of operation, the long time was required for increase of phosphorus removal efficiency. This is because the system further adapts to the input wastewater contents during that time, yielding a higher efficiency. Therefore, it is revealed that the $\mathrm{A}^{2} \mathrm{O}$ system by MBSBR has a high capability in removing phosphorus from municipal wastewater.

\section{Acknowledgemnts}

The aiuthors would like to express their full gratitude to all who made contribution to conduction of this study.

\section{References}

AGARWAL, S., TYAGI, I., GUPTA, V. K., DEHGHANI, M., JAAFARI, J., BALARAK, D. \& ASIF, M. 2016. Rapid removal of noxious nickel (II) using novel $\gamma$-alumina nanoparticles and multiwalled carbon nanotubes: Kinetic and isotherm studies. Journal of Molecular Liquids, 224, 618-623.

AHMED, M., IDRIS, A. \& ADAM, A. 2007. Combined anaerobic-aerobic system for treatment of textile wastewater. Journal of Engineering Science and Technology (JESTEC), 2, 55-69.

ARDEN, E. \& LOCKETT, W. 1914. The oxidation of sewage without the aid of filter. Part I and II. Journal of the Society of Chemical Industry, 33, 523-539.

ASHRAFI, S. D., KAMANI, H., JAAFARI, J. \& MAHVI, A. H. 2016. Experimental design and response surface modeling for optimization of fluoroquinolone removal from aqueous solution by $\mathrm{NaOH}$-modified rice husk. Desalination and Water Treatment, 57, 16456-16465.

BALARAK, D., JAAFARI, J., HASSANI, G., MAHDAVI, Y., TYAGI, I., AGARWAL, S. \& GUPTA, V. K. 2015. The use of low-cost adsorbent (Canola residues) for the adsorption of methylene blue from aqueous solution: Isotherm, kinetic and thermodynamic studies. Colloids and Interface Science Communications, 7, 16-19.

BESSBOUSSE, H., RHLALOU, T., VERCHÈRE, J.-F. \& LEBRUN, L. 2008. Removal of heavy metal ions from aqueous solutions by filtration with a novel complexing membrane containing poly (ethyleneimine) in a poly (vinyl alcohol) matrix. Journal of Membrane Science, 307, 249-259.

BINA, B., MOVAHEDIAN, H. \& POURZAMANI, H. R. 2005. Effect of influent COD/N ratio on nitrification rate in a bench-scale biological reactor. J. of Water and Wastewater, 53, 30-37.

BLANEY, L. M., CINAR, S. \& SENGUPTA, A. K. 2007. Hybrid anion exchanger for trace phosphate removal from water and wastewater. Water Research, 41, 1603-1613.

CHEN, H.-B., WANG, D.-B., LI, X.-M., YANG, Q., LUO, K. \& ZENG, G.-M. 2014. Temperature influence on biological phosphorus removal induced by aerobic/extended-idle regime. Environmental Science and Pollution Research, 21, 6034-6043. 
CHEN, H.-B., WANG, D.-B., LI, X.-M., YANG, Q. \& ZENG, G.-M. 2015. Enhancement of post-anoxic denitrification for biological nutrient removal: effect of different carbon sources. Environmental Science and Pollution Research, 22, 5887-5894.

CHEN, H., LIU, Y., NI, B.-J., WANG, Q., WANG, D., ZHANG, C., LI, X. \& ZENG, G. 2016. Full-scale evaluation of aerobic/extended-idle regime inducing biological phosphorus removal and its integration with intermittent sand filter to treat domestic sewage discharged from highway rest area. Biochemical Engineering Journal, 113, 114-122.

CLARK, T., STEPHENSON, T. \& PEARCE, P. 1997. Phosphorus removal by chemical precipitation in a biological aerated filter. Water research, 31, 2557-2563.

DEHGHANI, M. \& KERMANSHAHI, M. The study of biological efficiency of batch reactor consecutive for Phosphorus removal in wastewater of Shiraz city. 12th National Conference on Environmental Health, 2009.

ESFANDYARI, Y., MAHDAVI, Y., SEYEDSALEHI, M., HOSEINI, M., SAFARI, G. H., GHOZIKALI, M. G., KAMANI, H. \& JAAFARI, J. 2015. Degradation and biodegradability improvement of the olive mill wastewater by peroxi-electrocoagulation/electrooxidation-electroflotation process with bipolar aluminum electrodes. Environmental Science and Pollution Research, 22, 6288-6297.

GENG, Z., HALL, E. \& BERUBE, P. 2007. Membrane fouling mechanisms of a membrane enhanced biological phosphorus removal process. Journal of membrane science, 296, 93-101.

HASSANI, S., SEPAND, M., JAFARI, A., JAAFARI, J., REZAEE, R., ZEINALI, M., TAVAKOLI, F. \& RAZAVIAZARKHIAVI, K. 2014. Protective effects of curcumin and vitamin E against chlorpyrifosinduced lung oxidative damage. Human \& experimental toxicology, 0960327114550888.

IRANI, V., SEYEDSALEHI, M., SAJADI, S. A. A. \& EBRAHIMIARJESTAN, M. 2016. Assessment of the Performance of Microbial Fuel Cell (MFC) for the Removal of Nitrate from Water. Indian Journal of Science and Technology, 9.

J. JAAFARI, M. SEYEDSALEHI, G. H. SAFARI, M. EBRAHIMI ARJESTAN, H. BARZANOUNI, S. GHADIMI, H. KAMANI, P. HARATIPOUR 2017. Simultaneous biological organic matter and nutrient removal in an anaerobic/anoxic/oxic (A2O) moving bed biofilm reactor (MBBR) integrated system. International journal of Environmental Science and Technology. 14:291-304.

JAAFARI, J., MESDAGHINIA, A., NABIZADEH, R., HOSEINI, M. \& MAHVI, A. H. 2014. Influence of upflow velocity on performance and biofilm characteristics of Anaerobic Fluidized Bed Reactor (AFBR) in treating high-strength wastewater. Journal of Environmental Health Science and Engineering, 12, 1.

JAFARI, J., MESDAGHINIA, A., NABIZADEH, R., FARROKHI, M. \& MAHVI, A. H. 2013. Investigation of anaerobic fluidized bed reactor/aerobic mov-ing bed bio reactor (AFBR/MMBR) system for treatment of currant wastewater. Iranian journal of public health, 42, 860.

JAYARAJ, S. \& LATHA, P. 2010. Upflow anaerobic and aerobic fixed bed reactor for simultaneous COD and Nitrogen removal from municipal wastewater.

NAGHIPOUR, D., GHARIBI, H., TAGHAVI, K. \& JAAFARI, J. 2016. Influence of EDTA and NTA on heavy metal extraction from sandy-loam contaminated soils. Journal of Environmental Chemical Engineering, 4, 3512-3518.

NAGHIPOUR, D., TAGHAVI, K., JAAFARI, J., MAHDAVI, Y., GHANBARI GHOZIKALI, M., AMERI, R., JAMSHIDI, A. \& HOSSEIN MAHVI, A. 2015. Statistical modeling and optimization of the phosphorus biosorption by modified Lemna minor from aqueous solution using response surface methodology (RSM). Desalination and Water Treatment, 1-12.

RUSTEN, B., HEM, L. J. \& ØDEGAARD, H. 1995. Nitrification of municipal wastewater in moving-bed biofilm reactors. Water Environment Research, 67, 75-86.

SADLER, R., MAETAM, B., EDOKPOLO, B., CONNELL, D., YU, J., STEWART, D., PARK, M.-J., GRAY, D. \& LAKSONO, B. 2016. Health risk assessment for exposure to nitrate in drinking water from village wells in Semarang, Indonesia. Environmental Pollution, 216, 738-745.

SAFARI, G. H., ZARRABI, M., HOSEINI, M., KAMANI, H., JAAFARI, J. \& MAHVI, A. H. 2015. Trends of natural and acid-engineered pumice onto phosphorus ions in aquatic environment: adsorbent 
preparation, characterization, and kinetic and equilibrium modeling. Desalination and Water Treatment, 54, 3031-3043.

SEYEDSALEHI, M., GOODARZI, M. \& BARZANOUNI, H. Use of carbon in increasing the quality of drinking water-Case study: the wells of Savejbolagh villages.

SHAHMORADI, M. H., ZADE, B. A., TORABIAN, A. \& SALEHI, M. S. 2006. REMOVAL OF NITRATE FROM GROUND WATER USING ACTIVATED CARBON PREPARED FROM RICE HUSK AND SLUDGE OF PAPER INDUSTRY WASTEWATER TREATMENT.

TCHOBANOGLOUS, G., BURTON, F. \& STENSEL, H. 2003. Metcalf and Eddy Wastewater Engineering: Treatment and Reuse McGraw Hill. New York, NY, 384.

TIAN, S., JIANG, P., NING, P. \& SU, Y. 2009. Enhanced adsorption removal of phosphate from water by mixed lanthanum/aluminum pillared montmorillonite. Chemical Engineering Journal, 151, 141-148.

WANG, D., XU, Q., YANG, W., CHEN, H., LI, X., LIAO, D., YANG, G., YANG, Q. \& ZENG, G. 2014. A new configuration of sequencing batch reactor operated as a modified aerobic/extended-idle regime for simultaneously saving reactor volume and enhancing biological phosphorus removal. Biochemical Engineering Journal, 87, 15-24. 